\title{
Description of nutrient consumption based on the level of industrial food processing. National Survey on Nutrition and Health of 2005
}

\author{
Ignacio Drake, B.S. ${ }^{a}$ Enrique Abeyá Gilardon, M.D. ${ }^{a}$, Guadalupe Mangialavori, Magister ${ }^{a}$ \\ and Ana Biglieri, B.S. ${ }^{a}$
}

\begin{abstract}
Technological advances and changes in lifestyles reflect in a greater consumption of processed and ultra-processed foods compared to natural ones. Using data from the National Survey on Nutrition and Health, the consumption of these foods and their relation to living conditions were described in three age groups of Argentina (infants aged 6-23 months, children aged 2-5years, and women aged $10-49$ years).

Consumption among infants 6-23 months old is high in nutrients from natural foods: calcium $(75.9 \%)$, proteins $(72.7 \%)$, iron $(71.5 \%)$, and fiber $(68.9 \%)$. Among children 2-5 years old, consumption drops significantly. And among women, it drops even more. The proportion of the energy contribution from ultra-processed foods is higher in the high-income population compared to the low-income population across all groups.

Key words: food industry, epidemiology, Argentina, food, survey on nutrition.
\end{abstract}

http: / / dx.doi.org/10.5546/ aap.2018.eng.345

To cite: Drake I, Abeyá Gilardon E, Mangialavori G, Biglieri A. Description of nutrient consumption based on the level of industrial food processing. National Survey on Nutrition and Health of 2005. Arch Argent Pediatr 2018;116(5):345-352.

a. Department of Nutrition, National Board of Maternity, Childhood, and Adolescence, Autonomous City of Buenos Aires, Argentina.

E-mail address:

Ignacio Drake, B.S.: ignacio.drake@gmail. com

Funding:

None.

Conflict of interest: None.

Received: 7-28-2017 Accepted: 2-14-2018

\section{INTRODUCTION}

A sustained increase has been observed worldwide in the morbidity burden associated with non-communicable chronic diseases (NCCDs) and their determinants, especially overweight and obesity. 1,2 This problem has acquired the characteristics of a pandemic, and there is evidence that attributes it to an increased energy consumption from highly-processed foods and beverages. ${ }^{3}$ Such morbidity burden does not affect everyone equally: lowincome populations suffer a greater impact. ${ }^{4-6}$
For some time, the food industry has favored the thriving of ultraprocessed products with technological advances that reinforce the positive aspects of flavor, texture, smell, etc., but which are unhealthy and result in NCCDs. ${ }^{7,8}$ Likewise, ultra-processed products contain less proteins and fibers, more free sugars, sodium, total and saturated fats, and a high energy density; therefore, a high consumption of these products promotes extremely harmful nutritional profiles. The proposal to categorize foods based on their level of processing gained consensus and relevance to differentiate population eating patterns. ${ }^{8-10}$

Over the past two decades, according to the Survey on Household Expenditure conducted by the National Statistics and Censuses Institute of Argentina (Instituto Nacional de Estadística y Censos, INDEC), there has been a clear shift from the traditional diet based on fresh or minimally-processed foods towards an eating pattern based on ultra-processed foods. Such displacement leads to a decline in the quality of intake, with significant changes in fiber, fat, sodium, and free-sugar consumption ${ }^{11}$ and a major reduction in vitamin and mineral consumption.

The National Survey on Nutrition and Health (Encuesta Nacional de Nutrición y Salud, ENNyS) was conducted in Argentina in 2005 and described the big picture of the nutritional situation of different population groups, but data were not analyzed from the perspective of food processing techniques. The objective of this article was to describe 
the dietary intake of selected age groups from the Argentine population using the NOVA food classification, ${ }^{12}$ which considered the level of industrial food processing and related it to socioeconomic and geographic outcome measures.

\section{POPULATION AND METHODS}

The ENNyS was conducted using a multistage probability sampling of independent age groups from towns with more than 5000 inhabitants across Argentina. The details of the ENNyS sample design and population groups, as well as the methodological aspects, have been explained in previous publications. ${ }^{13,14}$ The study described here was carried out based on dietary intake records. Intake was estimated using the 24-hour dietary recall $(24 \mathrm{HR})$ method for infants aged 6-23 months, children aged 2-5 years, and women aged 10-49 years, who were representative of the population of each of the six regions of Argentina.

Quality of life indicators were used according to the INDEC's methodology to estimate unmet basic needs (UBNs), ${ }^{15}$ destitution line and poverty line (DL/PL), ${ }^{16}$ and quintile distribution of the per capita family income.

Foods were categorized based on the NOVA food classification. This classification categorizes foods into four groups based on their nature, and the extent and purpose of the processes applied to produce and / or preserve them based on the following characteristics:

- Group 1. Unprocessed or minimally processed foods: these are defined as parts of plants or animals that have not been subjected to industrial processes or that have been modified but without adding new substances (such as salt, sugar or oil); however, these foods may be altered by removing parts of them. Group 1 foods include fruits or vegetables, fresh or frozen meat, eggs, milk, and rice or other grains.

- Group 2. Processed culinary ingredients: these are substances obtained directly from unprocessed foods such as oil and sugar, or from nature, such as salt. Culinary ingredients are rarely consumed alone but used in combination with unprocessed or minimally processed foods in the kitchen to prepare other dishes.

- Group 3. Processed foods: these products are made by adding salt, oil, sugar or other culinary ingredients to minimally processed foods. Processed foods are still recognizable as modified versions of unprocessed foods; they include canned fruits or vegetables, salted nuts, cured or smoked meats, and cheese.

- Group 4. Ultra-processed foods: these are defined as industrial formulations with multiple ingredients; they include sugarsweetened beverages, packaged breads, cookies, savory snacks, confectionery, icecream, breakfast cereals, and frozen, ready-toeat products.

Each food mentioned during the $\mathrm{R} 24 \mathrm{H}$ was independently assigned by one of the team nutritionists to one of these four groups. Discrepancies were resolved by consensus.

Likewise, the chemical composition of each food was taken from the Analysis System and Food Registry (Sistema de análisis y registro de alimentos, SARA). The SARA database is made up of 379 foods, for which data on energy, proteins, lipids, carbohydrates, fiber, sodium, calcium, iron, saturated fatty acids (FAs), monounsaturated FAs, polyunsaturated FAs, and other data are available.

To estimate percentage values, the numerator was the sum of energy and nutrients provided by each food consumed based on the NOVA classification category, and the denominator was the sum of energy and/or nutrients provided by all foods recorded in the $\mathrm{R} 24 \mathrm{H}$.

\section{RESULTS}

The number of surveyed participants by region and age group is described in Table 1 of the Annex.

\section{Age group: 6-23 months old}

Among infants, the highest energy and nutrient intake was from natural foods and ingredients (Figure 1). In this regard, $75.9 \%$ of calcium, $72.7 \%$ of proteins, $71.5 \%$ of iron, and $68.9 \%$ of fiber were provided by NOVA group 1 foods. In addition, the proportion of processed products was low, except for saturated FAs $(63.4 \%)$, carbohydrates $(43.9 \%)$, and sodium $(40.3 \%)$.

When considering only group 4 foods (ultraprocessed products), differences in energy and nutrient intake based on UBNs were significant and varied up to 10 percentage points between infants who had UBNs and those who did not; this was similar when analyzed by DL/PL. However, among the higher-income quintiles, energy intake from ultra-processed products increased: it accounted for $19.5 \%$ in quintile 
1 among lower-income individuals versus $32.9 \%$ in quintile 5 among higher-income individuals (Figure 2). Although the proportion is lower than that observed in other population groups, it has been confirmed that the ability to generate income affects the types of processed products consumed, even among the youngest populations.

Considering consumption in this infant group by geographic distribution, it was observed that the lowest energy intake from ultra-processed products was recorded in the Northwest region of Argentina (NOA) and the Northeast region of Argentina (NEA) (approximately 19\%), followed by the Cuyo and Pampa regions (25\%), whereas the highest intake was observed in the Metropolitan Area of Buenos Aires (AMBA) and the Patagonia region (31\%).

The average nutritional content of foods consumed in this age group per NOVA group is presented in Table 2 of the Annex.

FIGURE 1. Relative energy and nutrient distribution according to the NOVA classification among infants aged 6-23 months (in percentage). $\mathrm{N}=6035$

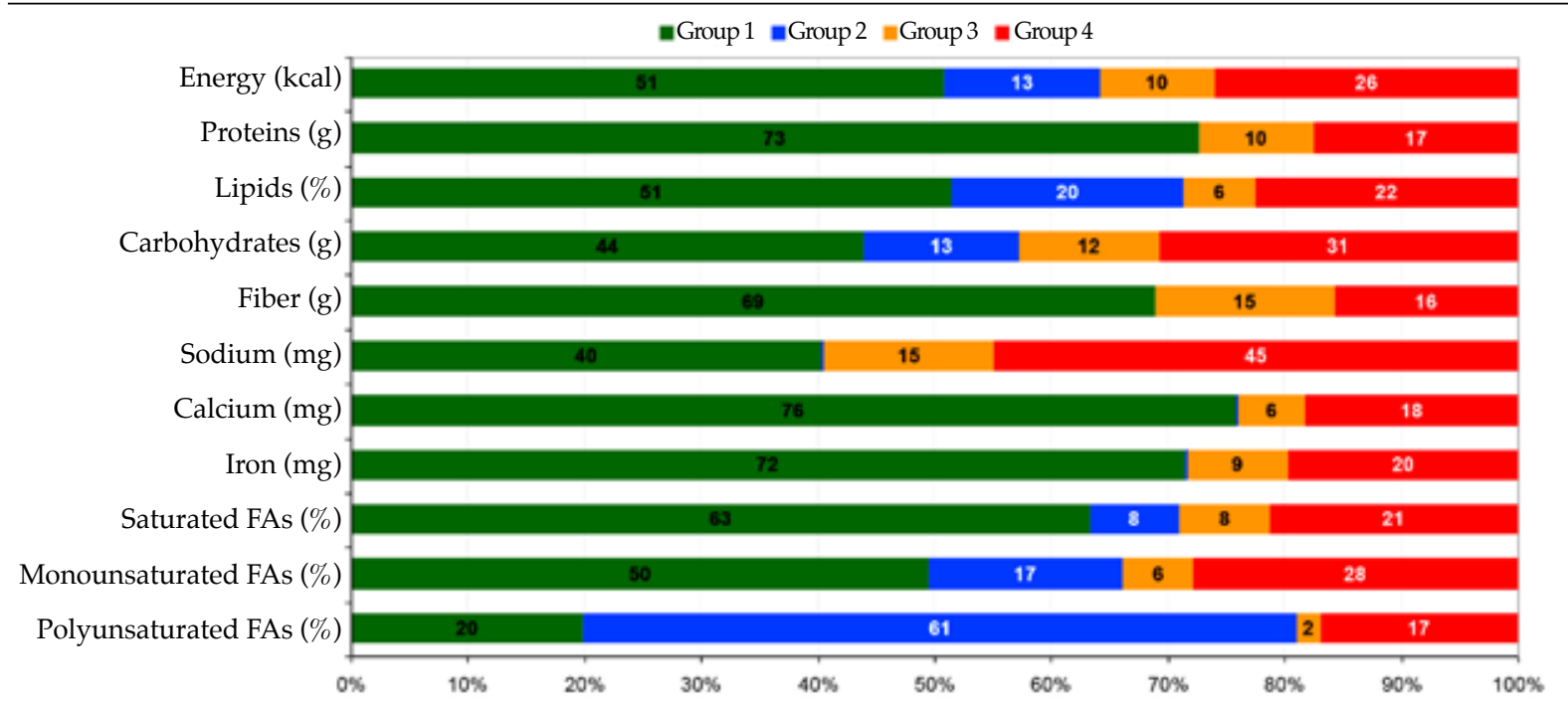

Source: Developed based on data from the ENNyS (2005) and Monteiro et al. (2011).

FAs: fatty acids.

FIGURE 2. Relative energy and nutrient distribution by quintile of the per capita family income according to the NOVA classification among infants aged 6-23 months (in percentage). N=6035

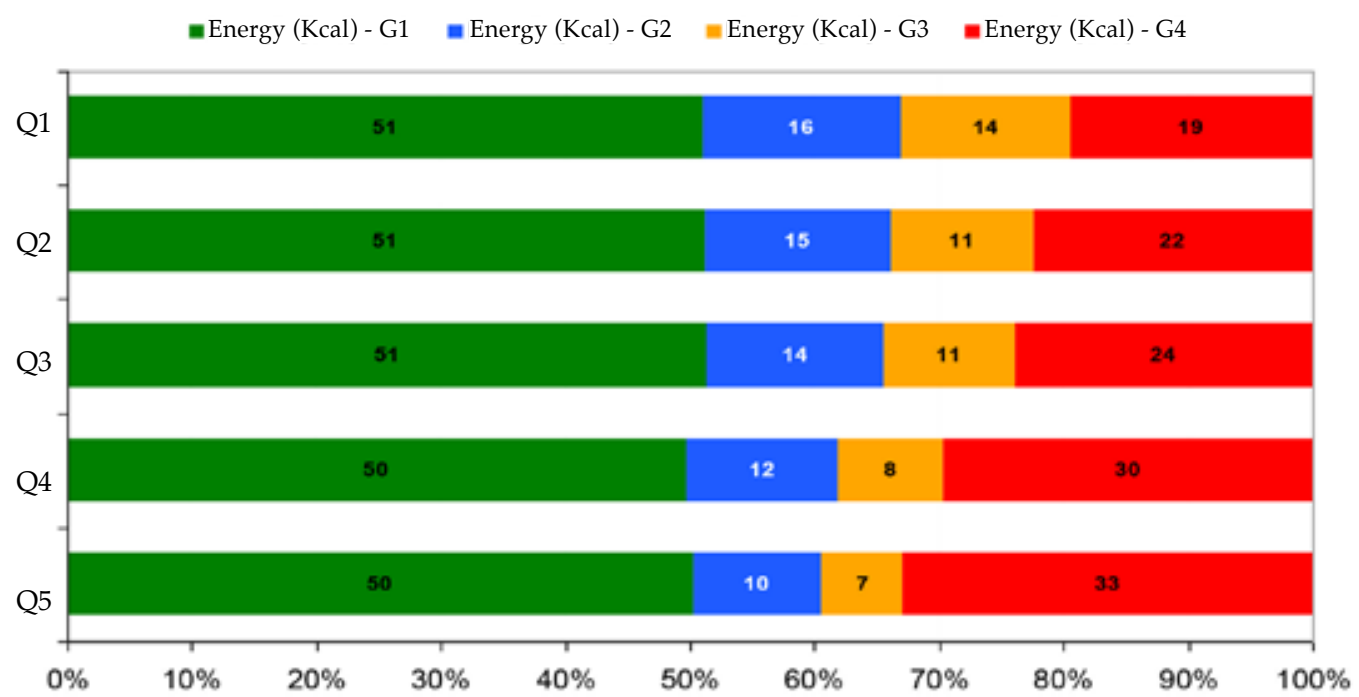

Source: Developed based on data from the ENNyS (2005) and Monteiro et al. (2011).

Q: quintile; G: group; Kcal: kilocalories. 


\section{Age group: 2-5 years old}

Unlike the previous age group, children in this group were already fully eating solid foods that they shared with the rest of their families. The energy and nutrient intake from natural foods and ingredients reduced significantly; $72.3 \%$ of calcium, $67.2 \%$ of proteins, $60.4 \%$ of iron, and $56.5 \%$ of fiber corresponded to this food group (Figure 3). However, the nutrient intake from ultra-processed products remained in the same levels as those observed for the previous age group.

A marked increase was observed in ultraprocessed product consumption among children in this age group living in households with a better quality of life, both among those without UBNs and those who were not considered poor. In both cases, the gap widened significantly between those with more and less deprivations, and it was even greater than in the previous group. Also in this regard, an important decrease was observed in the energy intake from natural foods (group 1) among the higher-income quintiles -approximately 10 percentage pointstogether with a leap in the energy intake due to the higher consumption of processed and ultraprocessed products (groups 3 and 4) among the higher-income quintiles (Figure 4).

In relation to energy consumption among children from all regions, the proportional energy intake was higher from ultra-processed foods at the expense of natural foods. As observed in the 6-23-month-old group, the higher consumption of processed and ultra-processed products was recorded in children from the AMBA and Patagonia regions. In relation to this type of products, children from these regions showed the highest intake values compared to the rest of the country.

The average nutritional content of foods consumed in this age group per NOVA group is presented in Table 3 of the Annex.

\section{Age group: 10-49 years old}

The analysis of this age group is also useful as a reference for food consumption among the adult population. It was observed that energy and nutrient intake from natural foods (group 1) was even lower than in the group of children aged 2-5 years. In this regard, only $59.0 \%$ of proteins, $55.1 \%$ of iron, $51.6 \%$ of fiber, and $46.4 \%$ of calcium came from natural foods (Figure 5). This older age group showed the lowest nutrient intake from natural foods among all analyzed groups.

In relation to the nutrient intake from ultraprocessed products, it was observed that women with less socioeconomic deprivations -without UBNs or not poor-consumed a higher proportion of nutrients from this type of products. Such intake was very similar to that observed in

FIGURE 3. Relative energy and nutrient distribution according to the NOVA classification among children aged 2-5 years (in percentage). $N=7364$

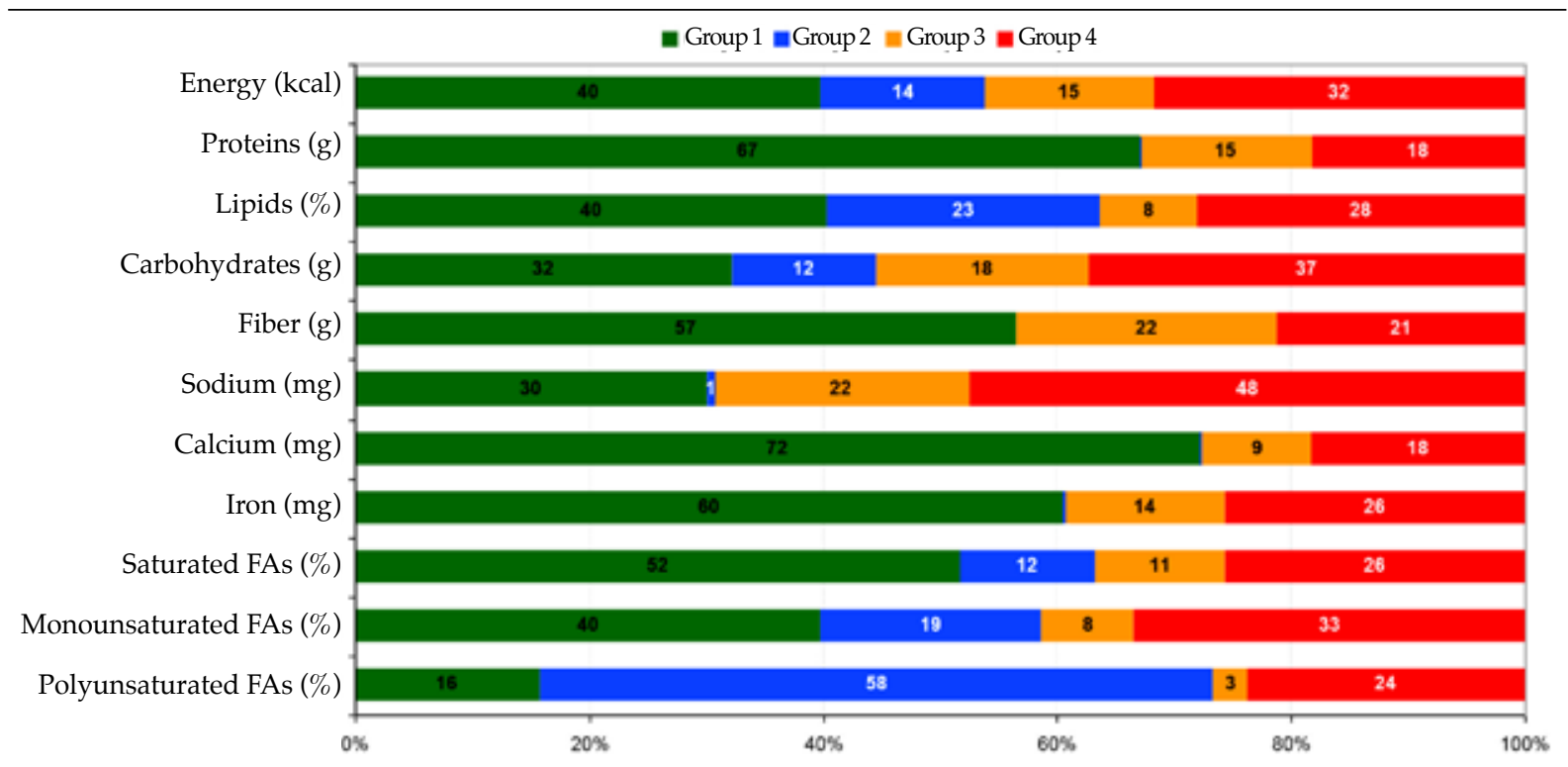

Source: Developed based on data from the ENNyS (2005) and Monteiro et al. (2011).

FAs: fatty acids. 
children aged 2-5 years. Consumption among women by income quintile showed that, across all strata, energy intake from natural or minimally processed foods was lower than in the previous group (approximately 10 percentage points lower) (Figure 6). However, the energy intake from ultraprocessed products was significantly higher as the level of income increased.
In relation to differences in consumption by geographic location, women from practically all regions consumed around 30\% of energy from natural or minimally-processed foods; the only exception was the NEA, where consumption accounted for $35.9 \%$. This was accompanied by a lower energy intake from ultra-processed products in the NOA, NEA, and Cuyo regions

FIGURE 4. Relative energy and nutrient distribution by quintile of the per capita family income according to the NOVA classification among children aged 2-5 years (in percentage). $N=7364$

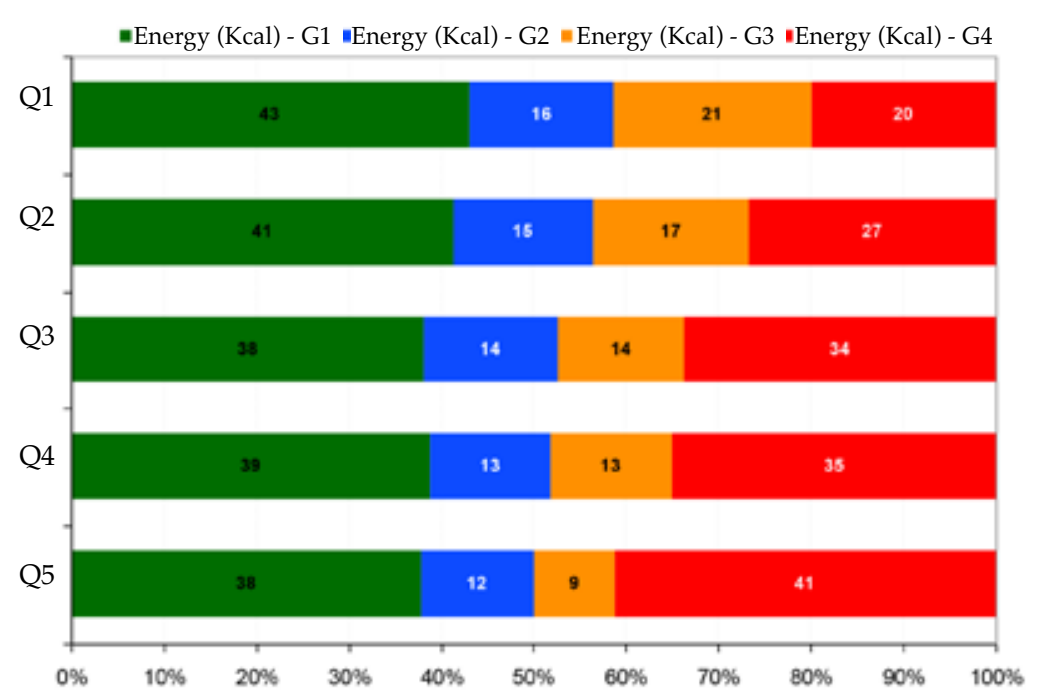

Source: Developed based on data from the ENNyS (2005) and Monteiro et al. (2011).

Q: quintile; G: group; Kcal: kilocalories.

FIGURE 5. Relative energy and nutrient distribution according to the NOVA classification among women aged 10-49 years (in percentage). $N=6605$

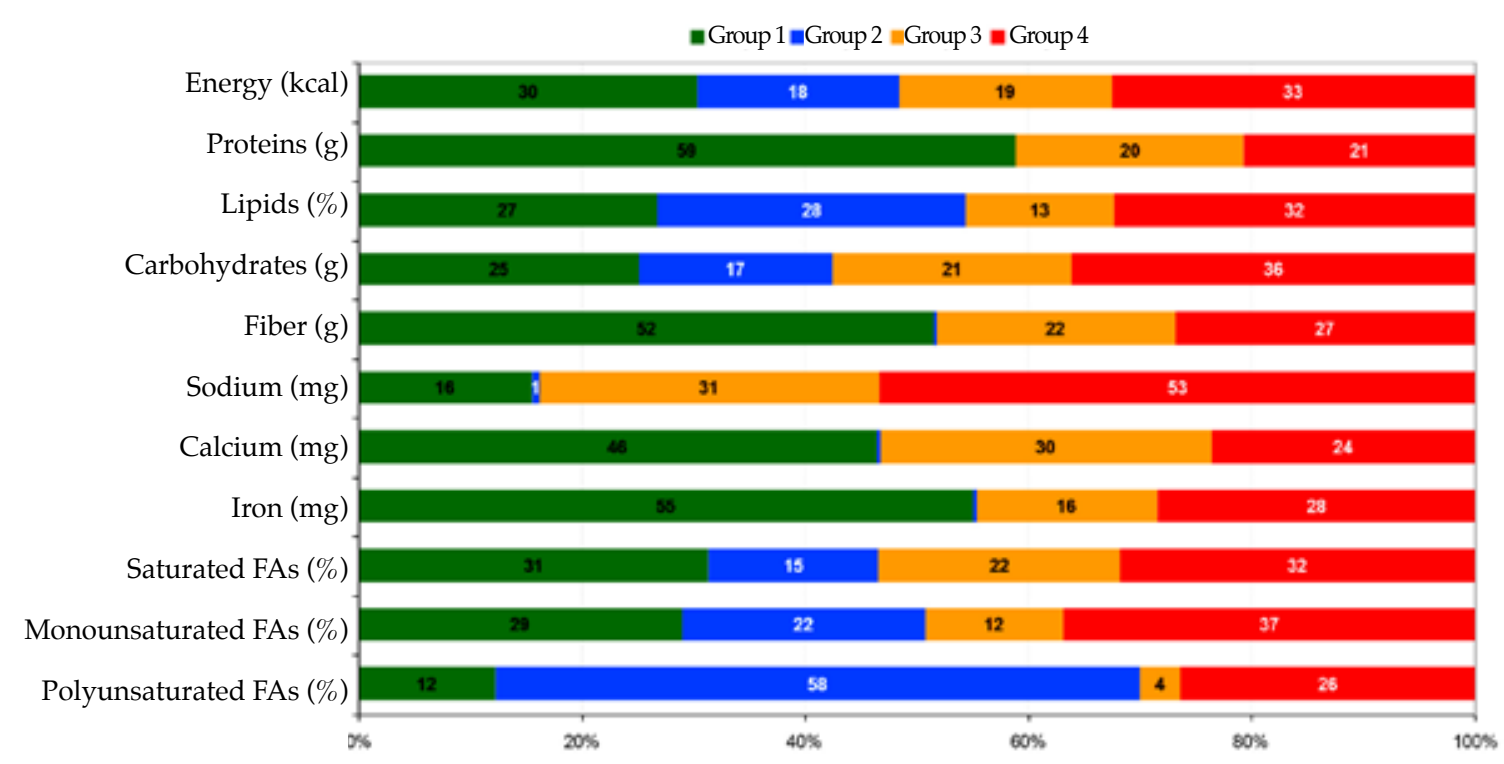

Source: Developed based on data from the ENNyS (2005) and Monteiro et al. (2011).

FAs: fatty acids. 
(approximately 26\%) and a significantly higher energy intake from this type of products in the Patagonia and AMBA regions (around 36\%).

The average nutritional content of foods consumed in this age group per NOVA group is presented in Table 4 of the Annex.

\section{DISCUSSION}

The bibliography on the description of dietary intake based on the chemical composition of foods is wide and varied and has made it possible to identify and measure nutrient requirements and the importance of nutrient deficiencies. Such description based on chemical composition guided the analysis of results of the ENNyS in 2007. There are similar reference frameworks that classify foods based on the level of processing. ${ }^{17,18}$ In our opinion, the most appropriate one is the NOVA classification; since 2014, the number of publications using the description of intake based on this reference framework has increased considerably in PubMed via Medline. This food classification system by processing level has gained recognition in the bibliography until the publication of a special issue of the leading journal in public nutrition policies in January $2018^{19}$ and as part of the reports by the Pan American Health Organization (PAHO) and the Food and Agriculture Organization (FAO), ${ }^{9,20}$
There is sufficient epidemiological evidence demonstrating that ultra-processed food consumption is associated with a low-quality diet and poor health conditions. ${ }^{21}$ The analysis of energy and nutrient intake based on the level of processing provides useful data to understand and implement health policies aimed at improving the nutritional status of a country's population. ${ }^{22}$ Although there are no current data on consumption in Argentina, intake analysis based on the data available from the ENNyS is useful to know consumption at critical ages, such as children younger than 6 years and women of childbearing potential.

The information on dietary intake analyzed here, even though it was obtained 12 years ago, is the only information available in Argentina with probabilistic representativeness and serves as the baseline for the comparison with future surveys so as to establish changes over time. Based on the population groups analyzed here, it was observed that as the population age increases, also does the contribution of energy and certain nutrients from ultra-processed foods.

Energy intake from ultra-processed foods in this study was higher than that estimated for Brazil using data from a survey on household expenditure for 2008-2009, which was equivalent to $21.5 \%$ of energy consumption, compared

FIGURE 6. Relative energy and nutrient distribution by quintile of the per capita family income according to the NOVA classification among women aged 10-49 years. $N=6605$

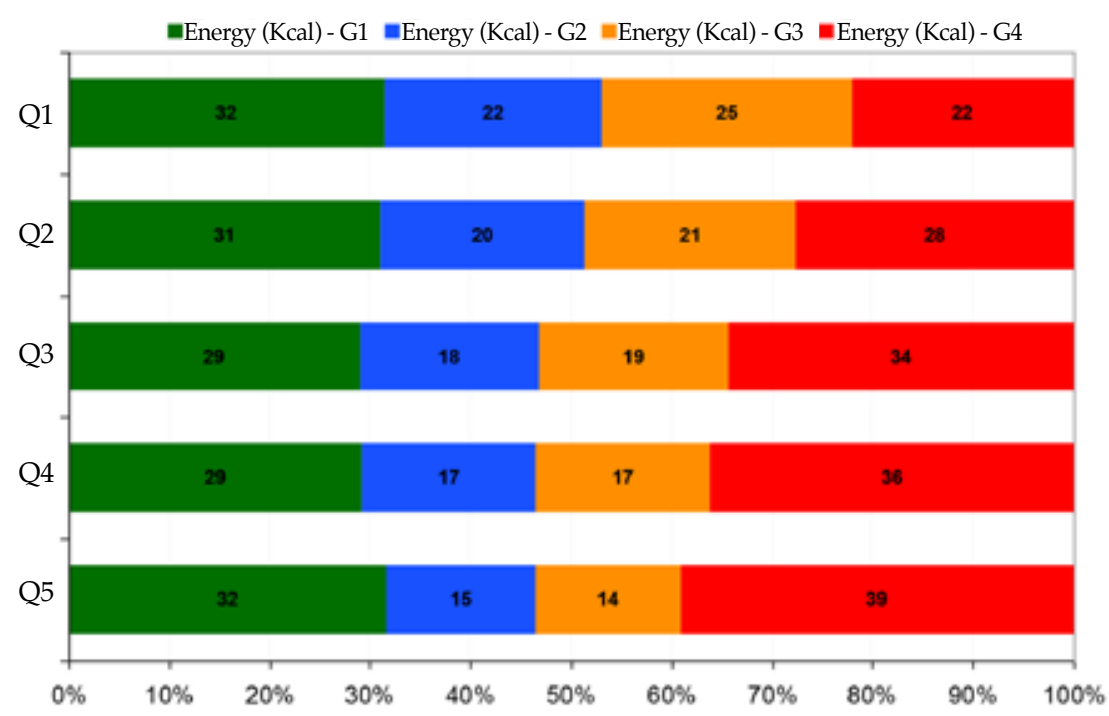

Source: Developed based on data from the ENNyS (2005) and Monteiro et al. (2011).

Q: quintile; G: group; Kcal: kilocalories. 
to our estimations, which were $26 \%, 32 \%$, and $33 \%$ among infants aged 6-23 months, children aged 2-5 years, and women aged $10-49$ years, respectively. ${ }^{23}$ In addition, an ecological, crosssectional study conducted in 19 European countries indicated that the median energy intake from ultra-processed foods at home was $26.4 \% .{ }^{24}$

This study showed a strong direct relationship between energy intake from ultra-processed foods and the family income, i.e., a higher per capita family income corresponded to a higher energy intake proportion from ultra-processed foods. Such direct relationship between family income and ultra-processed food consumption has also been observed in Brazil. Besides, this direct relationship takes place at a country level: the higher the domestic income, the higher the proportion of ultra-processed food consumption..$^{25}$

Among analyzed nutrients, sodium is the one that is most contributed by ultra-processed foods. Polyunsaturated FAs include trans fats, which were still used in the Argentine food industry in 2005, such as hydrogenated vegetable oils, because they were cheaper for the production of processed and ultra-processed foods. For this reason, the contribution of unprocessed foods to the consumption of polyunsaturated FAs appears to be relevant. In 2010, the Argentine Food Code forbade them. ${ }^{26}$ This state regulatory intervention has managed to reduce the consumption of trans fatty acids since then.

The strength of this study is that it estimated consumption in a probability sample of population groups which are a priority for public nutrition policies based on the reference framework of food processing level and in relation to overweight and obesity in the Argentine population. ${ }^{27-30}$ The analysis of what has occurred in the past two decades based on household expenditure shows a steady advance towards processed foods, from $19 \%$ of calorie intake in 1996-1997 to $29 \%$ in 2012-2013. ${ }^{31}$

The weakness of the study is that consumption corresponded to single records by person and intra-individual variability was not estimated, which causes some uncertainty in the estimations of confidence intervals of mean estimates. ${ }^{32}$

Monitoring the contribution of ultra-processed foods to usual energy intake may be a useful strategy to guide the promotion of public policies aimed at establishing healthy eating habits. It is known that the consumption of ultra-processed foods is associated with a poor-quality diet, and this has been the main argument to propose it as a population indicator of diet quality. ${ }^{33,34}$

\section{CONCLUSION}

Energy and nutrient intake from natural or minimally processed foods is higher in the first years of life. As older age population groups are taken into consideration, consumption of ultraprocessed foods increases. The consumption of this type of products is more common among higher socioeconomic levels or those with a better quality of life.

\section{Acknowledgments}

We would like to thank Luciana Paduano, B.S., for her help assigning foods to the NOVA classification, and Carlos Defrancisco, B.S., for processing and putting together the database.

\section{REFERENCES}

1. Ng M, Fleming T, Robinson M, et al. Global, regional, and national prevalence of overweight and obesity in children and adults during 1980-2013: a systematic analysis for the Global Burden of Disease Study 2013. Lancet 2014; 384(9945):766-81.

2. NCD Risk Factor Collaboration (NCD-RisC). Trends in adult body-mass index in 200 countries from 1975 to 2014 : a pooled analysis of 1698 population-based measurement studies with 19.2 million participants. Lancet 2016; 387(10026):1377-96.

3. Vandevijvere S, Chow CC, Hall KD, et al. Increased food energy supply as a major driver of the obesity epidemic: a global analysis. Bull World Health Organ 2015; 93(7):446-56.

4. Wang Y, Beydoun MA. The obesity epidemic in the United States- gender, age, socioeconomic, racial/ethnic, and geographic characteristics: a systematic review and metaregression analysis. Epidemiol Rev 2007; 29:6-28.

5. Wang Y, Lobstein T. Worldwide trends in childhood overweight and obesity. Int J Pediatr Obes 2006;1(1):11-25.

6. Wang Y. Disparities in pediatric obesity in the United States. Adv Nutr 2011; 2(1):23-31.

7. Breslin PA. An evolutionary perspective on food and human taste. Curr Biol 2013; 23(9):R409-18.

8. FAO/OPS. América Latina y el Caribe: Panorama de la seguridad alimentaria y nutricional. Sistemas alimentarios sostenibles para poner fin al hambre y la malnutrición. Santiago: OPS; 2017. [Accessed on: February 15th, 2018]. Disponible en: http: / / www.fao.org/3/a-i6747s.pdf.

9. OPS/OMS. Alimentos y bebidas ultraprocesados en América Latina: tendencias, efecto sobre la obesidad e implicaciones para las políticas públicas. Washington: OPS; 2015. [Accessed on: February 15th, 2018]. Available at: iris.paho.org/xmlui/bitstream/ handle/123456789/7698/9789275318645_esp.pdf.

10. Ludwig DS. Technology, diet, and the burden of chronic disease. JAMA 2011; 305(13):1352-3.

11. Zapata ME, Rovirosa A, Carmuega E. La mesa Argentina en las últimas dos décadas: cambios en el patrón de consumo de alimentos y nutrientes 1996-2013. Ciudad Autónoma de Buenos Aires: Centro de Estudios sobre Nutrición Infantil - CESNI; 2016.

12. Monteiro CA, Cannon G, Levy R, et al. Food classification. Public Health. NOVA. The star shines bright. World Nutr. 2016;7(1-3):28-38. [Accessed on: December 18th, 2017]. Available at: https://worldnutritionjournal.org/index. php/wn/article/view/5/4.

13. Durán P, Mangialavori G, Biglieri A, et al. Estudio descriptivo de la situación nutricional en niños de 6-72 
meses de la República Argentina. Resultados dela Encuesta Nacional de Nutrición y Salud (ENNyS). Arch Argent Pediatr 2009; 107(5): 397-404.

14. Ministerio de Salud. Encuesta Nacional de Nutrición y Salud. Documento de Resultados 2007. Buenos Aires: Ministerio de Salud, 2007. [Accessed on: December 18th, 2017]. Available at: http://datos.dinami.gov.ar/ produccion/nutricion/ennys.html.

15. INDEC. Mapa de necesidades básicas insatisfechas 2001. Aquíse Cuenta. 2003; 7. [Accessed on: February 15th, 2018]. Available at: https://www.indec.gov.ar/micro_sitios/ webcenso/aquisecuenta/aqui7.pdf.

16. Dirección Nacional de Encuestas de Hogares del INDEC. Acerca del método utilizado para medir la pobreza en la Argentina. Buenos Aires: INDEC. 2003. [Accessed on: February 15th, 2018]. Available at: https://www.indec. gob.ar/ftp/cuadros/sociedad/pobreza2.pdf.

17. Crino $M$, Barakat $T$, Trecena $H$, et al. Systematic review and comparison of classification frameworks describing the degree of food processing. Nutr Food Technol 2017; 3(1):138.

18. MoubaracJC, Parra DC, Cannon G, etal. Food Classification Systems Based on Food Processing: Significance and Implications for Policies and Actions: A Systematic Literature Review and Assessment. Curr Obes Rep 2014; 3(2):256-72.

19. Kelly B, Jacoby E. Public Health Nutrition special issue on ultra-processed foods. Public Health Nutr 2018; 21(1):1-4.

20. FAO. Guidelines on the collection of information on food processing through food consumption surveys. Roma: FAO; 2015. [Accessed on: December 18th, 2017]. Available at: http: / / www.fao.org/3/a-i4690e.pdf.

21. Batal M, Johnson-Down L, Moubarac JC, et al. Quantifying associations of the dietary share of ultra-processed foods with overall diet quality in First Nations peoples in the Canadian provinces of British Columbia, Alberta, Manitoba and Ontario. Public Health Nutr 2017; 21:103-13.

22. Monteiro CA, Cannon G, Moubarac JC, et al. The UN Decade of Nutrition, the NOVA food classification and the trouble with ultra-processing. Public Health Nutr 2017; 21(1):5-17.

23. Costa Louzada ML, Martins A, Canella D, et al. Ultraprocessed foods and the nutritional dietary profile in Brazil. Rev Saude Publica 2015; 49:38.
24. Monteiro CA, Moubarac JC, Levy RB, et al. Household availability of ultra-processed foods and obesity in nineteen European countries. Public Health Nutr 2018; 21(1):18-26.

25. Monteiro CA, Levy RB, Claro RM, et al. Increasing consumption of ultra-processed foods and likely impact on human health: evidence from Brazil. Public Health Nutr 2011; 14(1): 5-13.

26. Ministerio de Justicia y Derechos Humanos. Secretaría de Políticas, Regulacióne Institutosy Secretaría de Agricultura, Ganadería y Pesca. Código Alimentario Argentino. Resolución Conjunta 137/ 2010 y 941 / 2010 Modificación. Buenos Aires, 3 de diciembre de 2010. [Accessed on: December 18th, 2017]. Available at:http:/ / servicios.infoleg. gob.ar/infolegInternet/anexos/175000-179999/176669/ norma.htm.

27. Galante M, Konfino J, Ondarsuhu D, et al. Principales resultados de la tercera Encuesta Nacional de Factores de Riesgo de enfermedades no transmisibles en Argentina. Rev Argent Salud Pública 2015; 6(24):22-9.

28. Datum Internacional. PERCEPCIÓN Y REALIDAD. Un estudio sobre obesidad en América. Octubre de 2014. [Accessed on: February 15th, 2018]. Available at: http:/ / docplayer.es / 15684192-Percepcion-y-realidad-un-estudiosobre-obesidad-en-america-octubre-2014.html.

29. Zapata ME. Patrón de consumo de bebidas en Argentina: resultados de los estudios Hidratar I y II. In: Carmuega E. (editor). Hidratación saludable en la infancia. Buenos Aires: CESNI, 2015.Págs.119-41.

30. Euromonitor International. Carbonates in Argentina. 2017. [Accessed on: December 18th, 2017]. Available at:http:/ / www.euromonitor.com/carbonates-in-argentina/report.

31. Zapata ME, Rovirosa A, Carmuega E. Cambios en el patrón de consumo de alimentos y bebidas en Argentina, 19962013. Salud Colectiva 2016; 12(4):473-86.

32. Gibson R, Charrondiere R, Bell W. Measurement errors in dietary assessment using self-reported 24-hour recalls in low-income countries and strategies for their prevention. Adv Nutr 2017; 8(6):980-91.

33. Vandevijvere S, Monteiro C, Krebs-Smith SM, et al. Monitoring and benchmarking population diet quality globally: a step-wise approach. Obes Rev 2013; 14(Suppl 1):135-49.

34. Popkin BM, Adair LS, Ng SW. Now and then: The global nutrition transition: the pandemic of obesity in developing countries. Nutr Rev 2012; 70(1):3-21. 


\section{ANNEX}

TABLE 1. Number of surveyed participants by age group and region

\begin{tabular}{lccc} 
Region & \multicolumn{2}{c}{$\begin{array}{c}\text { Age group } \\
\text { Infants aged 6-23 months Children aged 2-5 years Women aged 10-49 years }\end{array}$} \\
\hline $\begin{array}{l}\text { AMBA } \\
\text { (CABA and Greater Buenos Aires districts) }\end{array}$ & 682 & 1012 & 854 \\
$\begin{array}{l}\text { Cuyo (Mendoza, San Juan, and San Luis) } \\
\text { NEA (Chaco, Corrientes, Formosa, and Misiones) }\end{array}$ & 1004 & 1230 & 1089 \\
$\begin{array}{l}\text { NOA (Catamarca, Jujuy, La Rioja, Salta, } \\
\text { Santiago del Estero, and Tucumán) }\end{array}$ & 1042 & 1270 & 1169 \\
$\begin{array}{l}\text { Pampa region (rest of Buenos Aires, Córdoba, } \\
\text { Entre Ríos, and Santa Fe) }\end{array}$ & 1203 & 1361 & 1259 \\
$\begin{array}{l}\text { Patagonia (Chubut, La Pampa, Neuquén, } \\
\text { Río Negro, Santa Cruz, and Tierra del Fuego) }\end{array}$ & 966 & 1221 & 1047 \\
Argentina & 1138 & 1270 & 6605 \\
\hline
\end{tabular}

Source: ENNyS 2005.

AMBA: Metropolitan Area of Buenos Aires; CABA: Autonomous City of Buenos Aires; NOA: Northwest region of Argentina;

NEA: Northeast region of Argentina.

TABLE 2. Average nutritional content of consumed foods per NOVA group. Infants aged 6-23 months.

Total for the country. $N=6035$

\begin{tabular}{lccccc}
\hline & Total & G1 & G2 & G3 & G4 \\
\hline Energy (kcal) & 1175.4 & 558.7 & 161.3 & 138.2 & 317.2 \\
Proteins (g) & 45.3 & 31.7 & 0.0 & 5.5 & 8.1 \\
Saturated FAs* & 13.2 & 15.9 & 8.9 & 11.6 & 9.6 \\
Monounsaturated FAs* $_{\text {Polyunsaturated FAs* }}^{*}$ & 10.1 & 9.7 & 13.7 & 6.6 & 9.8 \\
Lipids (g) & 5.9 & 2.3 & 26.4 & 1.3 & 3.3 \\
Available carbohydrates (g) & 41.4 & 20.0 & 8.7 & 3.1 & 9.6 \\
Fiber (g) & 155.5 & 63.1 & 20.8 & 22.0 & 49.6 \\
Sodium (mg) & 5.8 & 3.7 & 0.0 & 1.1 & 1.0 \\
Calcium (mg) & 855.4 & 316.8 & 2.7 & 147.1 & 388.8 \\
\hline
\end{tabular}

G1: unprocessed foods; G2: ingredients; G3: processed foods; G4: ultra-processed foods.

FA: fatty acids; Kcal: kilocalories; G: group; g: grams; mg: milligrams.

*: Percentage over total energy intake.

**: Estimated only for infants aged 13-23 months because there are no recommendations for younger infants.

TABLE 3. Average nutritional content of consumed foods per NOVA group. Children aged 2-5 years.

Total for the country. $N=7364$

\begin{tabular}{lccccc}
\hline & Total & G1 & G2 & G3 & G4 \\
\hline Energy (kcal) & 1683.5 & 646.1 & 234.7 & 262.3 & 540.4 \\
Proteins (g) & 59.9 & 39.3 & 0.0 & 9.5 & 11.0 \\
Saturated FAs* & 11.8 & 15.1 & 9.7 & 10.8 & 8.2 \\
Monounsaturated FAs* $^{*}$ & 10.3 & 10.3 & 13.9 & 6.9 & 9.3 \\
Polyunsaturated FAs* & 6.4 & 2.6 & 26.2 & 1.4 & 3.9 \\
Lipids (g) & 58.4 & 22.7 & 13.9 & 5.4 & 16.5 \\
Available carbohydrates (g) & 229.6 & 71.2 & 27.4 & 44.0 & 86.9 \\
Fiber (g) & 8.6 & 4.7 & 0.0 & 2.0 & 1.9 \\
Sodium (mg) & 1152.0 & 329.7 & 6.1 & 266.3 & 550.0 \\
Calcium (mg) & 761.0 & 540.3 & 0.7 & 81.1 & 138.9 \\
\hline
\end{tabular}

G1: unprocessed foods; G2: ingredients; G3: processed foods; G4: ultra-processed foods.

FA: fatty acids; Kcal: kilocalories; G: group; g: grams; mg: milligrams.

*: Percentage over total energy intake. 
II / Arch Argent Pediatr 2018;116(5):345-352 / Special article

TABLE 4. Average nutritional content of consumed foods per NOVA group. Women aged 10-49 years.

Total for the country. $\mathrm{N}=6605$

\begin{tabular}{|c|c|c|c|c|c|}
\hline & Total & G1 & G2 & G3 & G4 \\
\hline Energy (kcal) & 2038.4 & 635.2 & 370.0 & 441.9 & 591.3 \\
\hline Proteins (g) & 68.9 & 40.0 & 0.0 & 16.1 & 12.8 \\
\hline Saturated FAs* & 10.0 & 10.7 & 8.8 & 10.7 & 8.7 \\
\hline Monounsaturated FAs* & 10.2 & 9.7 & 13.3 & 7.0 & 10.1 \\
\hline Polyunsaturated FAs* & 6.7 & 2.7 & 23.0 & 1.4 & 4.6 \\
\hline Lipids (g) & 67.9 & 17.4 & 18.7 & 9.7 & 22.1 \\
\hline Available carbohydrates (g) & 250.6 & 61.1 & 41.7 & 55.7 & 92.1 \\
\hline Fiber (g) & 13.4 & 7.2 & 0.0 & 3.3 & 2.9 \\
\hline Sodium (mg) & 1391.4 & 235.5 & 7.8 & 463.5 & 684.6 \\
\hline Calcium (mg) & 473.4 & 210.9 & 0.9 & 151.2 & 110.3 \\
\hline
\end{tabular}

G1: unprocessed foods; G2: ingredients; G3: processed foods; G4: ultra-processed foods.

FA: fatty acids; Kcal: kilocalories; G: group; g: grams; mg: milligrams.

*: Percentage over total energy intake. 